\title{
Effects of Some Antioxidants on in Vitro Rooting of Apple Shoots
}

\author{
Alvaro Standardi and Fausto Romani \\ Istituto Coltivazioni Arboree, Università di Perugia, Borgo XX Giugno, \\ 06100 Perugia, Italy
}

Additional index words. micropropagation, antioxidants, Malus domestica

\begin{abstract}
In vitro-proliferated shoots of 'Delicious' and 'Starkspur Red' apples (Malus domestica Borkh.) were submitted for 1 week to root induction in the dark with their basal parts in liquid medium containing $1.5 \mu \mathrm{M}$ IBA and $43.4 \mathrm{~mm}$ sucrose. The shoots were transferred to root initiation and root elongation medium made up of plugs wetted with half-strength Lepoivre salts. When antioxidants, such as PVP, GH, 2-Me, and DIECA, were added to the liquid induction medium, the percentages of rooting usually decreased. In contrast, if the antioxidants PVP and citric acid were added in the initiation-elongation medium, the percentages of rooting increased. The results agree with the finding of other researchers who proposed a rapid increase in peroxidase activity during root induction followed by a fast decline during rooting initiation as a marker for good rooting responses. Moreover, the use of antioxidants both in induction and in initiation-elongation had no effect on number and length of roots. Chemical names used: polyvinylpyrrolidone-40 (PVP); glutathione reduced (GH); 2-mercaptoethanol (2-Me); diethyldithiocarbamic acid, sodium salt trihydrate (DIECA); $N$ - (phenyl-

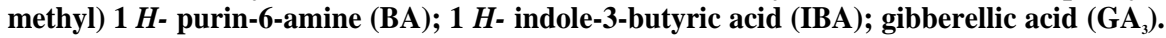

In several tree species, rooting remains one of the most critical steps of the micropropagation technique. Moncousin and Gaspar (1983) reported that in Cynara scolymus, a herbaceous plant, high rooting responses corresponded to increases in peroxidase (EC 1.11.1.7) activity during induction and a rapid decrease in the same enzymatic activity during initiation-elongation phase.

Usually variations in peroxidase activity and rooting responses have been obtained by application of light, auxin, temperature, and/ or phenols at the proper time (Debergh, 1987; Druart et al., 1982; James, 1983; Quoirin et al., 1974; Standardi, 1985; Zimmerman, 1984). Recently, De Klerk et. al. (1989) observed a correlation between peroxidase activity, time of shoot transplanting, and rooting quality in shoots of apple, without finding the pathway proposed by Moncousin and Gaspar (1983).

The time of application of the factors able to interfere with peroxidase activity and, consequently, with the rooting process, is very important. Some researchers have proposed that it is possible to subject the shoots to the root-induction step (the others are initiation and elongation) during the last week of proliferation (Debergh, 1987; Druart et al., 1982), whereas others believe that induction begins after the separation of the shoots from the clumps proliferated at the end of a subculture (Amitrani et al., 1989; Standardi, 1985; Zimmerman, 1984; Zimmerman and Fordham, 1985).

Received for publication 15 Dec. 1989. Research carried out with financial support from the Italian Dept. of Education (M.P.I., 60\% Fund). The cost of publishing this paper was defrayed in part by the payment of page charges. Under postal regulations, this paper therefore must be hereby marked advertisement solely to indicate this fact.
In this experiment, the direct administration of antioxidants during induction and also during initiation-elongation of roots was examined.

Cultures of 'Delicious' and 'Starkspur Red' were initiated from meristems collected from buds, using procedures and environmental conditions described by Jacoboni and Standardi (1982). Shoots were proliferated on medium containing Lepoivre salts (Quoirin and Lepoivre, 1977) supplemented with 0.56 mM myo-inositol, $1.18 \mu \mathrm{M}$ thiamine- $\mathrm{HCl}$, $2.18 \mu \mathrm{M}$ BA, $1.47 \mu \mathrm{M} \mathrm{GA}_{3}, 86.7 \mathrm{~mm}$ sucrose, and $7 \mathrm{~g}$ purified agar/liter (Merck, code 1614).

Terminal shoot cuttings 1.5 to $2.0 \mathrm{~cm}$ long were prepared from proliferating cultures, retaining the leaves only at the apical $1 \mathrm{~cm}$ of the shoots. Groups of 10 shoots were placed upright in $25 \times 95-\mathrm{mm}$ shell vials containing $3 \mathrm{ml}$ of autoclave liquid medium composed of $1.5 \mu \mathrm{M} \mathrm{IBA}$ and $43.4 \mathrm{~mm}$ sucrose
(Zimmerman and Fordham, 1985). The cultures were incubated in darkness for 1 week in a growth chamber maintained at $24 \pm 1 \mathrm{C}$.

The shoots were then transferred into 500$\mathrm{ml}$ jars containing 20 Milcap plugs (one explant per plug Fig. 1) previously wetted with half-strength Lepoivre salts and autoclave at $115 \mathrm{C}$ for $20 \mathrm{~min}$. During rooting, cultures were grown at $25 \pm 1 \mathrm{C}$ with a 16 -hr photoperiod provided by warm-white fluorescent lights at a photon flux density of 50 to $60 \mu \mathrm{mol} \cdot \mathrm{s}^{-1} \cdot \mathrm{m}^{-2}$.

The antioxidants ( $0.25 \mathrm{~mm}$ PVP; $1.61 \mathrm{~mm}$ $\mathrm{GH}$; $6.25 \mathrm{~mm}$ 2-ME; and $83.33 \mathrm{~mm}$ DIECA) were used during the inductive phase where they were added to the vials containing $3 \mathrm{ml}$ of liquid medium. During the initiation and elongation steps, where the chemicals were put into the jars containing the Milcap plugs, we used $25 \mu \mathrm{M}$ PVP; $1.30 \mathrm{~mm}$ 1.30; 1.05 $\mathrm{mm}$ citric acid; and $1.11 \mathrm{~mm}$ ascorbic acid. The substances were added to liquid medium or to Milcap plugs by sterile filtration; the control contained no antioxidants.

The substances and the concentrations were chosen on the basis of preliminary experiments in which various quantities were tested. Their persistence in the media and sensivitity of the shoots to them were considered.

In each treatment, 40 shoots were employed (10 explants $\times$ four replications). Data on number of cuttings rooted and length and number of roots per plantlet were collected 4 weeks after initiation of the experiment.

In 'Delicious' all the compounds significantly reduced rooting compared the control when applied at induction, whereas in 'Starkspur Red' only GH and PVP reduced rooting (Table 1). Consequently, cultivars appear to differ in sensitivity to antioxidants tested in the first step of rooting.

Among the compounds tested during initiation and elongation of roots, the highest rooting percentages, which were higher than for the control, were found in both cultivars treated with GH or citric acid. PVP and ascorbic acid gave results similar to the control (Table 1). The ineffectiveness of the last two substances may be related to the concentrations assayed.

Table 1. Effect of antioxidants applied at two stages on rooting and on the percentage of dead explants of 'Delicious' and 'Starkspur Red' apple (each mean was calculated from 40 cuttings).

\begin{tabular}{|c|c|c|c|c|}
\hline \multirow{2}{*}{$\begin{array}{l}\text { Stage of } \\
\text { application } \\
\text { and antioxidant }\end{array}$} & \multicolumn{2}{|c|}{ Cuttings rooted $(\%)^{y}$} & \multicolumn{2}{|c|}{$\begin{array}{l}\text { Explants dead at end } \\
\text { of experiment }(\%)\end{array}$} \\
\hline & Delicious & Starkspur Red & Delicious & Starkspur Red \\
\hline \multicolumn{5}{|l|}{ Induction } \\
\hline PVP & $20.0 \mathrm{c}$ & $21.5 \mathrm{~d}$ & 5.0 & 7.5 \\
\hline GH & $11.1 \mathrm{~d}$ & $32.1 \mathrm{c}$ & 10.0 & 5.0 \\
\hline $2-\mathrm{Me}$ & $25.0 \mathrm{c}$ & $47.8 \mathrm{~b}$ & 7.5 & 7.5 \\
\hline DIECA & $26.3 \mathrm{c}$ & $53.1 \mathrm{~b}$ & 12.5 & 7.5 \\
\hline \multicolumn{5}{|c|}{ Initiation-elongation } \\
\hline PVP & $52.5 \mathrm{~b}$ & $52.5 \mathrm{~b}$ & 2.5 & 0.0 \\
\hline $\mathrm{GH}$ & $62.5 \mathrm{a}$ & $71.6 \mathrm{a}$ & 5.0 & 2.5 \\
\hline Citric acid & $69.3 \mathrm{a}$ & $75.4 \mathrm{a}$ & 0.0 & 0.0 \\
\hline Ascorbic acid & $50.0 \mathrm{~b}$ & $54.6 \mathrm{~b}$ & 5.0 & 2.5 \\
\hline Control & $49.4 \mathrm{~b}$ & $54.6 \mathrm{~b}$ & 0.0 & 0.0 \\
\hline
\end{tabular}

zPVP $=$ polyvinylpyrrolidone-40; $\mathrm{GH}=$ glutathione reduced; 2 -Me $=2$-mercaptoethanol; $\mathrm{DIECA}=$ diethyldithiocarbamic acid.

yMeans separation in columns by Duncan's multiple range test, $P=0.05$. 


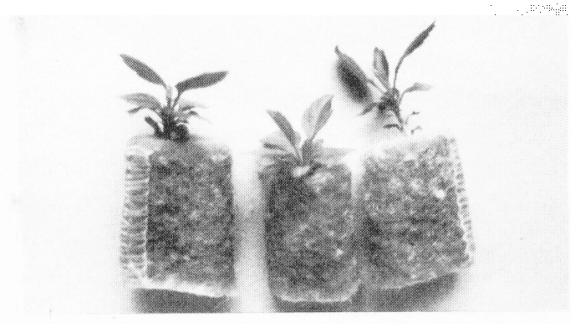

Fig. 1. Shoots in Milcap plugs during root elongation.

The antioxidants used did not influence number (range per plant 1.4 to 1.9 , 'Delicious'; 1.4 to 1.8 , 'Starkspur Red') or length (14 to $21 \mathrm{~mm}$,'Delicious'; 5 to $8 \mathrm{~mm}$ 'Starkspur Red') of roots following any treatment.

These results indicate that using antioxidants to reduce peroxidase activity during induction inhibits rooting, whereas applying antioxidants to reduce peroxidase activity during the initiation and elongation of roots promotes rooting. Consequently, the suggestion of Moncousin and Gaspar (1983) that the rapid increase in peroxidase activity during root induction and the fast decline at root initiation as a marker for good rooting in Cynara scolymus appears to be confirmed from the results of this experiment with 'Delicious' and 'Starkspur Red' apple. This result is also in agreement with the work of Druart et al. (1982).

Nevertheless, other investigations measuring peroxidase activities during the rooting steps in explants treated with antioxidants at different intervals and concentrations are necessary to verify the validity of the above suppositions. In this experiment some treatments caused the death of explants (Table $1)$.

Although some biochemical and physiological aspects of the rooting process remain unknown, this experiment clearly showed that some antioxidants positively or negatively influence this important phase of micropropagation, depending on the time of their application.

\section{Literature Cited}

Amitrani, A., F. Romani, and A. Standardi, 1989. Influenza del momento di applicazione dell'acido indol-3-butirrico e dell'oscuramento nella radicazione di germogli di M.27 micropropagati. Agr. Med. 119:417-423.

Debergh, P.C. 1987. Improving micropropagation. I.A.P.T.C. Nwsl. 51:2-10.

De Klerk, G.J., J. ter Brugge, R. Smulders, and M. Benschop. 1989. Basic peroxidases and rooting in microcuttings of Malus. Proc. Intl. Symp. on In Vitro Culture and Hort. Breeding. Cesena, Italy. p. 18.

Druart, P., C. Kevers, P. Boxus, and T. Gaspar. 1982. In vitro promotion of root formation by apple shoots through darkness effect on endogenous phenols and peroxidases. Z. Pflanzenphysiol. 108:429-436

Jacoboni, A. and A. Standardi. 1982. La rnoltiplicazione in vitro del melo cv Wellspur. Rivista dell'Ortoflorofruit. Italia 66:217-229.

James, D.J. 1983. Adventitious root formation in vitro in apple root stocks (Malus pumila). I:
Factors affecting the length of auxin-sensitive phase in M.9. Physiol. Plant. 57:149-153.

Moncousin, C. and T. Gaspar. 1983. Peroxidase as a marker for rooting improvement of Cynara scolymus L. cultured in vitro. Biochem. Physiol. Pflanzen 178:263-271.

Quoirin, M., P. Boxus, and T. Gaspar. 1974. Root initiation and isoperoxidases in stem tip cuttings from mature Prunus plants. Physiol. Vég. 12(2): $165-174$

Quoirin, M. and P. Lepoivre. 1977. Etude de milieux adaptes aux cultures in vitro de Prunus.
Acta Hort. 78:437-442.

Standardi, A. 1985. Effetto della luce, del carbone attivo e dell'IBA sulla radicazione in vitro di germogli di melo. Ann. Fac. Agr. Univ. Perugia 33:109-120.

Zimmerman, R.H. 1984. Rooting apple cultivars in vitro: Interactions among light, temperature, phlorglucinol and auxin. Plant Cell Tissue Organ Culture 3:301-311.

Zimmerman, R.H. and I. Fordham. 1985. Simplified method for rooting apple cultivars in vitro. J. Amer. Soc. Hort. Sci. 110:34-38. 